\title{
TWO VIEWS OF WHITMAN IN 1856: UNCOLLECTED REVIEWS OF LEAVES OF GRASS FROM THE New York DAILY NEWS AND FRANK LESLIE'S ILLUSTRATED NEWSPAPER
}

\section{Steven Olsen-SMith}

After Kenneth M. Price's edition of Walt Whitman: The Contemporary Reviews went to press, ${ }^{1}$ I discovered new 1856 reviews of Leaves of Grass. The first, from the February 27 New York Daily News, reviews the first edition of Leaves (not a "new edition" as the reviewer claimed.) The second, from the December 20 Frank Leslie's Illustrated Newspaper (New York), postdates the second edition of Leaves, but the reviewer's physical description of the book indicates that he also was noticing the first edition. The zeal of both reviewers, distinguished by clashing appraisals of Whitman, makes it particularly fortunate that these pieces are now available to supplement Price's important collection.

Here in full is the New York Daily News review of February 27, 1856, when the paper was edited by Gideon J. Tucker. This review will intrigue Whitman enthusiasts for a number of reasons, not least the author's description of Whitman's frontispiece portrait in Leaves:

LEAvES of Grass. Entered according to Act of Congress, by Walter Whitman, \&c., \&c. Brooklyn.

A new edition, we believe, of the famous Whitman's poems, which made such a flutter among the "gray goose quills" of this city and "other quarters of the globe" some time ago. Of the poem which occupies the ninety-five pages of this folio, we have before briefly spoken. Upon examining it a second time, and pondering its aims and expressions, we feel constrained to say that it is certainly the strangest, most extraordinary production we have ever attempted to peruse. Still, like the rest of our contrymen, we are by no means either averse to extraordinary things or afraid of them. We enjoy enterprise in speech and writing as thoroughly as in steam vessels, revolving rifles or new-found Nicaraguas. Therefore we shall not quarrel with $\mathrm{Mr}$. Whitman for being odd. Oddness is the normal condition of some natures - of the freshest and best, perhaps - at least when it means frankness and opposition to solemn propriety, alias humbug and red tape.

Mr. Whitman's preface is what the hum-drum world calls "queer" as entirely perhaps as his poem, yet we think a great deal of it both finely and bravely uttered as well as true. None can, more than we do, entirely hate that cant which always ascribes this or that kind of writing to this or the other "school," as if the young author had necessarily in every instance copied some model; as if two similarly constituted minds 
may not naturally seek similar expression! It is precisely this stupid, stereotyped classification adopted by indolent or clique-led reviewers, that has produced so many abortions in literature through the straining after at least the appearance of total originality, but to give future readers of this book some indication of its style, ere they have opened it, we will say that it is Germanic and Carlylean-even Emersoniansometimes in the strain of Martin Farquhar Tupper, although far stronger and more pointed than the latter.

The poem exhibits undoubted and striking evidence of genius and power. But the author reasoning that the spirit of the American people, nay, of any people is chiefly represented by its uncultivated though, perhaps, naturally intelligent classes, falls into the error of mistaking their frequent uncouthness as a fair revelation of that spirit, and the bathos often produced in some of his finest passages by the presence of this idea defaces his work and repels hundreds of candid minds who would be eager to acknowledge his claims, but are thus prevented from reading enough to recognize them.

In glancing rapidly over the "Leaves of Grass" you are puzzled whether to set the author down as a madman or an opium eater; when you have studied them you recognize a poet of extraordinary vigor, nay even beauty of thought, beneath the most fantastic possible garments of diction. If Hamlet had gone mad, in Ophelia's way, as well as in his own, and in addition to his own vein of madness, he might, when transported to our own age and country, have talked thus.

In a crush hat and red shirt open at the neck, without waistcoat or jacket, one hand on his hip and the other thrust into his pocket, Walt Whitman the b'hoy poet, on his muscle, writes sentences like these:

"A child said, What is grass? - fetching it to me with full hands.

How could I answer the child .... I do not know what it is any more than he.

And now it seems to me the beautiful uncut hair of graves.

This grass is very dark to be from the white heads of old mothers.

Darker than the colorless beards of old men,

Dark to come from under the faint red roofs of mouths.

Oh I perceive, after all, so many uttering tongues!

And I perceive they do not come from the roofs of mouths for nothing.["]

Again:

["]Press close, bare bosomed night! Press close magnetic nourishing night!

Night of South winds! Night of the large few stars!

Still nodding night! Mad naked Summer night!

Sea breathing broad and convulsive breaths!

Sea of the brine of life! Sea of unshovelled and always ready graves!”

His own picture:

"Walt Whitman, an American, one of the roughs, a Kosmos, Disorderly, fleshy, sensual .... eating, drinking and breeding, No sentimentalist .... no stander above men and women or apart from them .... no more modest than immodest." 
Yet, he is a sentimentalist! Read the lines beginning

"I believe a leaf of grass is no less than the journey work of the stars, \&c.- "

$\mathrm{He}$ is a painter, carver and sculptor:

"A gigantic beauty of a stallion, fresh and responsive to my caresses, Head high in the forehead and between the ears, Limbs glossy and supple, tail dusting the ground, Eyes well apart and full of sparkling wickedness .... ears finely cut and flexibly moving."

$\mathrm{He}$ is a genuine "rough"- a male muse in horse-blanket and boots. Sometimes he is "Mose;"

$\mathrm{He}$ enjoys "he-festivals with blackguard gibes, and ironical license, and bull dances, and drinking, and laughter." Then he is

"Pleased with primitive tunes of the choir of the white-washed church,"

And then you see him

"Walking the old hills of Judea with the beautiful gentle god by his side."

Now, with him, we

"Visit the orchards of God, and look at the spheric product,

And look at quintillions ripened, and look at quintillions green."

Or

"Go hunting polar furs and the seal . . . . leaping chasms with a pike-pointed staff .... clinging to topples of brittle and blue.["]

Read this noble passage:

"How the skipper saw the crowded and rudderless wreck of the steamship, and death chasing it up and down the storm,

How he knuckled tight and gave not back one inch, and was faithful of days and faithful of nights,

And chalked in large letters on a board; $\mathrm{Be}$ of good cheer, We will not desert you;

How he saved the drifting company at last,

How the lank loose-gowned women looked when boated from the side of their prepared graves.

How the silent old-faced infants, and the lifted sick, and the sharp-lipped unshaven men;[.]"

We are tempted to quote many strophes from this remarkable collection of genius inebriated with its own overflowing fountains of fancy, but must conclude with the following fine lines, referring to past struggles for freedom, and predicting a future: 
["] Meanwhile corpses lie in new-made graves .... bloody corpses of young men:

The rope of the gibbet hangs heavily .... the bullets of princes are flying .... the creatures of power laugh aloud,

And all these things bear fruits .... and they are good.

Those corpses of young men,

Those martyrs that hang from the gibbets .... those hearts pierced by the gray lead,

Cold and motionless as they seem .... live elsewhere with unslaughter'd vitality.

They live in other young men, O kings,

They live in brothers, again ready to defy you:

They were purified by death .... They were taught and exalted.

Not a grave of the murdered for freedom but grows seed for freedom .... in its turn to bear seed,

Which the winds carry afar and re-sow, and the rains and the snows nourish.

Not a disembodied spirit can the weapons of tyrants let loose,

But it stalks invisibly over the earth .... whispering counseling cautioning.

Liberty let others despair of you .... I never despair of you.

Is the house shut? Is the master away?

Nevertheless be ready . . . . be not weary of watching,

He will soon return .... his messengers come anon.["]

For the sum of 75 cents any reader may accompany Whitman through a poetic chaos-bright, dark, splendid, common, ridiculous and sublime-in which are floating the nebulæ and germs of matter for a starry universe of organized and harmonious systems that may yet revolve, in all the magnificence of artistic order, through the highest heaven of fame!

As proof that whatever may be the merits or demerits of this singular production, we may state that very many thousand copies have been sold and the demand is still increasing.

I have examined in vain the fragmentary Daily News files at the New York Public Library and the New York Historical Society in search of the prior notice of Leaves alluded to in the opening paragraph of the review. Recovery of the prior notice seems especially desirable considering the intelligence and ebullience of the author's appraisal.

Here in full is the December 20, 1856, Frank Leslie's Illustrated Newspaper review, equally intelligent although ferociously hostile:

\section{Leaves of Grass. By Walt Whitman.}

We find upon our table (and shall put into the fire) a thin octavo volume, handsomely printed and bound, with the above curious title. We shall not aid in extending the sale of this intensely vulgar, nay, absolutely beastly book, by telling our readers where it may be purchased. The only review we shall attempt of it, will be to thus publicly call the attention of the grand jury to a matter that needs presentment by them, and to mildly suggest that the author should be sent to a lunatic asylum, and the mercenary publishers to the penitentiary for pandering to the prurient tastes of morbid sensualists. Ralph W. Emerson's name appears as an indorser of these (so-called) poems (?)God save the mark! We can only account for this strange fatuity upon the supposition 
that the letter is a forgery, that Mr. E. has not read some passages in the book, or that he lends his name to this vile production of a vitiated nature or diseased imagination, because the author is an imitator of his style, and apes him occasionally in his transcendentalisms. Affectation is as pitiful an ambition in literature as alliteration, and never has it been more fully exhibited during the present century than in the case of Thomas Carlyle, a man with an order of intellect approaching genius, but who for a distinguishing mark to point like a finger-board to himself, left a very terse and effective style of writing to adopt a jargon filled with new-fangled phrases and ungrammatical super-superlative adjectives- $\mathrm{Mr}$. Carlyle buried himself for a long time in German universities and German philosophy, and came forth clothed in a full "old clothes" suit of transcendentalism worthy of the Chatham street embodiments of that pseudo-philosophy, Kant and Spinosa [sic] - Carlyle by this operation became a full-fledged Psyche from the chrysalis, and sported in the sunshine of popularity, whereupon a young gentleman ambitious of making New England an umbra of Scottish-Germanic glory, one Ralph Waldo Emerson, suddenly transforms himself into a metaphysical transcendentalist and begins talking about "Objective and Subjective," the "Inner and Outer," the "Real and Ideal," the "God-heads and Godtails," "Planes," "Spheres," "Finite, Infinite," "Unities," and "Dualities," "Squills, Ipecac," "Cascading and Cavorting," \&c., \&c. And lo! another appeared after this Mr. Emerson, one Walt Whitman, who kicked over the whole bucket of the Milky Way, and deluged the world with the whey, curds and bonny-clabber of Brooklynwhich has resulted from the turning of the milk of human kindness in a "b'hoy's" brains to the cream of Tartar-and a delicious dish of the same is now furnished under cover of Leaves of Grass, and indorsed by the said Emerson, who swallows down Whitman's vulgarity and beastliness as if they were curds and whey. No wonder the Boston female schools are demoralized when Emerson, the head of the moral and solid people of Boston, indorses Whitman, and thus drags his slimy work into the sanctum of New England firesides.

I have left both reviews unattributed for lack of evidence. A possible but unlikely candidate for either review, oddly enough, is the English literary man, Thomas Powell. Hershel Parker identified Powell as the author of a review of Melville's Piazza Tales in the May 26, 1856 New York Daily News, ${ }^{3}$ but Powell's tenure with the Daily News appears not to have begun until mid-March of that year, shortly after the February review of Leaves appeared. The Dictionary of American Biography reports that Powell was "the first editor of Frank Leslie's Illustrated Nerwspaper, established in 1855," and that he stayed on with the Frank Leslie publishing house all his life. ${ }^{4}$ Powell's known comments on Carlyle and Emerson, ${ }^{5}$ however, do not sufficiently resemble those of the Frank Leslie's reviewer to justify an attribution.

It would be particularly worthwhile to learn the identity of the Daily News reviewer, who may in some capacity have been familiar with Whitman since he realized that in the black and white frontispiece portrait Whitman wore a "red shirt." Presumably he meant the exposed portion of undershirt, although his wording suggests Whitman's obviously light-colored overshirt, "open at the neck." We know from Bronson 
Alcott that Whitman indeed sometimes wore a "Red flannel undershirt" in $1856,{ }^{6}$ but whether the Daily News reviewer actually knew Whitman's person or just made an informed guess about the generic color of the shirt remains to be known.

As I found after discovering the two reviews, Whitman included the Daily News and Leslie's Illustrated Nerws among twenty-two other New York newspaper and periodical titles entered by him along with their street locations into a notebook that Harold Blodgett dates between July 1855 and September $1856,{ }^{7}$ now most widely available as the "George Walker" manuscript entry in volume 1 of Whitman's Notebooks and Unpublished Prose Manuscripts. ${ }^{8}$ Also among the entries ("checked off by ticks" according to Edward F. Grier, editor of Notebooks [239n]) are the Crayon (signified by Whitman's listing of its editors, "Stillman \& Durand"), the Sunday Leader and the Ledger, three serials that noticed Leaves in January, June and May of 1856, respectively. Probably using the compilation as a checklist of projected recipients, Whitman appears to have marked each title once he had submitted a review copy of Leaves to that particular establishment. If, as Grier's wording suggests, Whitman checked off every one of the twenty-four serial titles he listed, one can speculate that a good many more New York reviews of the 1855 and 1856 Leaves of Grass appeared than we have yet been able to acknowledge, some of which may still survive in library files.

\section{University of Delaware}

\section{NOTES}

1 Cambridge: Cambridge University Press, 1996. Professor Price generously shared with me the 1855-56 reviews in his then unpublished collection.

2 The smoking and spitting Bowery fireman and b'hoy portrayed in a number of stage productions, beginning in 1848 with Benjamin A. Baker's "A Glance at New York in 1848," and named in association with Whitman also by the reviewer of Leaves in the February 18 Daily National Intelligencer [Washington, D.C.] (see Price, 37).

3 Brian Higgins and Hershel Parker, eds. Herman Melville: The Contemporary Reviews (Cambridge University Press, 1995), 470.

4 Edwin Francis Edgett, "Powell, Thomas," Dictionary of American Biography vol. 7, ed. Dumas Malone (New York: Charles Scribner's Sons, 1935), 151.

5 Such as those on Carlyle in the August 25, 1856 issue of the New York Daily News and in Living Authors of England (New York: D. Appleton, 1849), 232-245, and on Emerson in Living Authors of America (New York: Stringer and Townsend, 1850), 49-77. 
6 The fournals of Bronson Alcott, ed. Odell Shepard (Boston: Little, Brown and Company, 1938), 286.

7 Walt Whitman: An 1855-56 Notebook Toward the Second Edition of Leaves of Grass (Carbondale: Southern Illinois University Press, 1959).

8 Family Notes and Autobiography, Brooklyn and New York, ed. Edward F. Grier (New York: New York University Press, 1984), 239-249. 